\title{
LIFE CYCLE ASSESSMENT AS A TOOL OF ENVIRONMENTAL SAFETY IN CAR RECYCLING
}

Numerous and wide-ranging initiatives are being pursued all over the world today to help pass on a sound natural environment to future generations. Automotive production is one of Slovakian leading industries. Because of urgent priority on protecting the environment, it is inevitable for manufacturers to be engaged in ongoing efforts to develop more environmentally friendly automobiles and a more viable infrastructure for them - one in which provisions for environmental protection, including recycling, constitute an essential part. The Life Cycle A ssessment (LCA) is a tool for the systematic evaluation of the environmental aspects of a product or service system through all stages of its life cycle. The article is focused on some possibilities of improving the environmental safety of motor vehicles especially by application of the LCA in automobile production.

Keywords: End-of-Life Vehicles (ELV), Life Cycle Assessment, Recycling, Environmental Performance

\section{The Reality of Recycling End-of-Life vehicles (ELV)}

After years of debate between the car manufacturers and government officials, the End-of-Life Directive 2000/53/EC from the European commission was published in October 2000, combining requirements for the European Member States (e.g. recycling limits to be met as from $1^{\text {st }}$ January 2006, collection of ELV's), requirements for vehicle manufacturers (e.g. reduction of heavy metals as from $1^{\text {st }}$ July 2003 , availability of relevant information) as well as obliging the European Commission itself to amend existing European legislation (Whole Vehicle Type Approval: recyclability calculation). The End-of-Life Directive was implemented in Slovakian legislation by adoption of directive no. 125/2004. In order to meet all these requirements, close cooperation of all involved stakeholders is a must considering the "cradle to grave" philosophy. [1]

European member states had the obligation to implement the requirements of the ELV Directive into their national laws by $21^{\text {st }}$ April 2002, however, some countries took up to Spring 2005. The EU ELV Directive also left the possibility to each of these member states how to arrange their national procedures for collection and treatment of ELV's; moreover, the member states were allowed to apply stricter measures (e.g. The Netherlands - which requires a 95\% recycling target for 2007 instead of 2015). Harmonization throughout Europe is also not supported by the fact that enforcement mechanisms vary between countries, states (e.g. Germany) and sometimes even regions (e.g. Belgium).

Meeting the recycling and recovery target as set by the EU ELV Directive is an issue for the European member state authorities; however they will have to rely on data gathered via various economic operators and according to the procedures from each member states. Here again an example that not the same data will be collected/required and thus could result in not the correct results when following the UE Commission Decision 2005/293/EC which sets out the rules on monitoring the reuse/recycling and reuse/ recovery targets.

\section{ELVs: A Valuable Source of Raw Materials}

End-of-life vehicles present a valuable source or raw materials (table 1, figure 1) with a wealth of potential, which can be after appropriate selection and further processing used as input for further production. [4]

The changing automotive material mix over the past fifteen years and evolutionary technology trends for the future relative to automobile architecture for improved safety and environmental performance have and will continue to increase the recycling technical challenge.

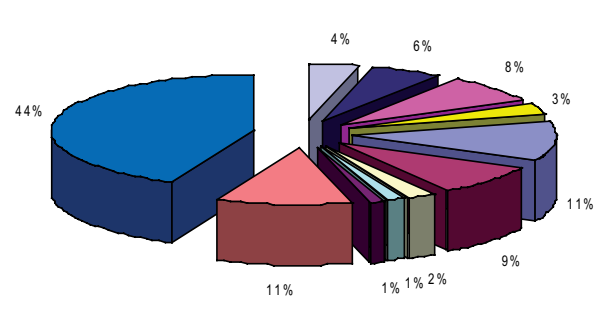
$\square$ Polymer a Aluminium $\square$ Copper $\square$ Lead $\square$ Zinc $\square$ Iron a Steel $\square$ Glass Rubber $\square$ Grease $\square$ others

Fig. 1 Percentage of car materials

\footnotetext{
* Milan Majernik, Jana Chovancova, Imrich Fekete

Department of Environmental Studies and Process Management, Faculty of Mechanical Engineering, Technical University of Kosice, E-mail: milan.majernik@tuke.sk
} 
Car materials

\begin{tabular}{|c|c|c|}
\hline Materials & Percentage & Weight $[\mathrm{kg} / \mathrm{car}]$ \\
\hline Polymer & 11.4 & 116 \\
\hline Aluminium & 8.9 & 91 \\
\hline Copper & 2.2 & 22 \\
\hline Lead & 1.5 & 15 \\
\hline Zinc & 1 & 110 \\
\hline Iron & 11 & 113 \\
\hline Steel & 43.3 & 442 \\
\hline Glass & 3.7 & 38 \\
\hline Rubber & 6 & 61 \\
\hline Grease & 7.9 & 81 \\
\hline Others & 3.1 & 32 \\
\hline Total & $100 \%$ & $1021 \mathrm{~kg}$ \\
\hline
\end{tabular}

\section{Improvement of Environmental Safety of Motor Vehicles}

In order to provide society with products that help promote the protection of the environment and the conservation of resources, manufacturers have to adopt some basic guidelines in the conduct of their activities. These activities can be summarised in following four points:

1. Manufacturers will make comprehensive assessments of the environmental impact of the vehicles they produce, beginning at the vehicle development stage, in their effort to provide automobiles that are more environmentally friendly. In the manufacturing process, too, they will strive to develop cleaner production technologies.

2. Manufacturers will seek to establish a recycling-based infrastructure for automobiles to help promote environmental protection.

3. On a global scale and through international cooperation, manufacturers will strive for increased environmental protection through the application of appropriate technologies and their own expertise.

4. Manufacturers will, in addition, promote internal organizational systems that allow for appropriate and timely action in response to all environmental issues related to motor vehicles.

The objective is to use life cycle analysis to assess the environmental impacts of various mechanical separation technologies and alternative end-of-life recycling technologies. This information will then be used to create a flexible, computerized life-cycle inventory model, which is process-specific and yet can be modified to include additional recycling technologies and various material inputs.

\section{Vehicle design and Development using LCA Methods}

During the past two decades, a process called the life cycle assessment was developed that tried to make consistent and objective environmental assessments. Recently the LCA is a potentially powerful tool which can assist regulators to formulate environmental legislation, help manufacturers analyse their processes and improve their products, and perhaps enable consumers to make more informed choices. Like most tools, it must be correctly used, however.

Focusing on every stage of the life cycle of their products, manufacturers aim to reduce the environmental impact of motor vehicles. By application of the life cycle analysis (LCA) methods, manufacturers are making increased efforts to develop new, advanced technologies that will also satisfy important criteria in the areas of safety reliability, convenience and comfort.

The LCA methods are drawing more and more attention around the world as a means of quantitatively assessing the environmental impact of a product throughout its life cycle - from the development of raw materials and parts production through assembly, delivery, and use of the product in the market throughout the service stage, to the recycling of used components. Moreover, the International Organization for Standardization has established standards for the LCA (ISO 14 04X). [2]

However, numerous problems remain in the application of the LCA methods to the production, use and recycling of automobiles, owing to the fact that most vehicles are composed of at least twenty to thirty thousand parts. Stages of the Life cycle of motor vehicles is demonstrated in figure 2 .

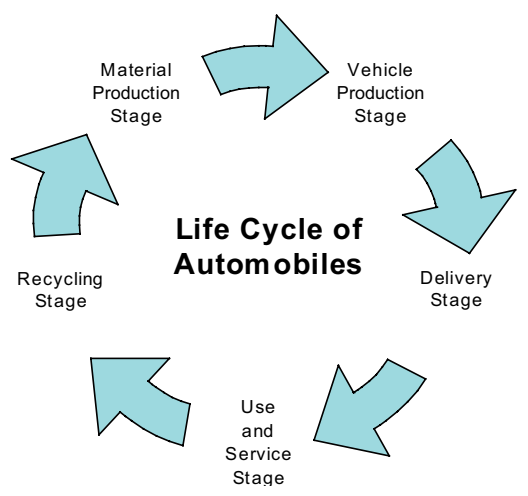

Fig. 2 Stages of Life Cycle of motor vehicles

In cases where contrary environmental goals exist the Life Cycle Assessment recommends the alternative that ensures the better overall environmental improvements. Therefore several studies were carried out on the dismantling and recycling process. These studies suggest certain life cycle aspects of different materials, constructions and drive systems. 
All these studies showed that in comparison to production and use phase, recycling and disposal have only little impact on the overall environmental performance. [6] The main environmental aspects for recycling and recovery are the avoidance of landfill and the replacement of primary resources.

Both are common practice for all metals used. For plastics and other organic materials we've learned from external studies [7], that every option which leads to a replacement of primary (fossil) resources is nearly equal from an environmental point of view. The studies pointed out that mechanical recycling, energy recovery and feedstock recycling provides equal environmental performance. In short terms: there is no environmental waste hierarchy detectable for automotive wastes. On the other hand studies show that the economic burdens for dismantling and mechanical recycling, depending on the type of component, is at least twice up to 14 times higher than the expenses for post shredder recovery options. The main reasons for this are found in time consuming dismantling, high processing costs and additional logistics.

The conclusion from a life cycle perspective is not to focus on a very specific recycling methodology that might have slight advantages but to widen the scope of technologies applied for end-of-life vehicle recycling in general. Consequently, end-of-life vehicle recycling should not be focused on material recycling but must include feedstock recycling as well as other technologies able to replace primary resources. [5] These technologies can treat the entire waste stream or a major part of it and thus will provide a wider benefit to end-of-life vehicle recycling than a material recycling focussing on pure polymers only. In short term:

- the Life Cycle Assessment is a valuable tool for a holistic assessment of the environmental performance of components.

- A number of the Life Cycle Assessment case studies demonstrated that the environmental differences of the different options to treat non metal waste streams (e.g. material recycling, feedstock recycling, energy recovery) is little or negligible for end-of-life vehicles. Consequently no justification for an artificial waste hierarchy was found.

- In particular for complex and long life products like automobiles the results of the Life Cycle Assessment suggest a holistic approach taking into account all environmentally relevant life cycle stages rather than focussing on a specific life stages only.

- The use of the Life Cycle Assessment during product design in particular for conceptual decisions is a useful instrument to ensure that the environmental impact over the entire life cycle is taken into account. This will prevent different life cycle aspects being overrated wile others may be impaired.

\section{Conclusions}

The LCAs might be conducted by an automobile production to enable it to identify areas where improvements can be made, in environmental terms. Alternatively the LCA may be intended to provide environmental data for the public or for government. In recent years, a number of major companies have cited the LCAs in their marketing and advertising, to support claims that their products are 'environmentally friendly' or even 'environmentally superior' to those of their rivals. Many of these claims have been successfully challenged by environmental groups.

All products have some impact on the environment. Since some products use more resources, cause more pollution or generate more waste than others, the aim is to identify those, which are most harmful.

Even for those products whose environmental burdens are relatively low, the LCA should help to identify those stages in production processes and in use which cause or have the potential to cause pollution, and those which have a heavy material or energy demand.

Breaking down the manufacturing process into such a fine detail can also be an aid to identifying the use of scarce resources, showing where a more sustainable product could be substituted.

Since the disclosure of the EU directive on end-of-life vehicles a number of relevant developments can be recognised. In the past the recycling hierarchy was seen as the ecological guideline. [3] Based on this perception manual dismantling of plastic components was seen as a prerequisite. However, the latest results of Life Cycle Assessment case studies suggest a more holistic approach on environmental targets.

This should trigger a reconsideration of the basic demands and strategies for end-of-life vehicle recycling in the future as well as a discussion on the implementation of these requirements in product design and recycling processes in the member states.

The presented results are part of solution of the project KEGA no. 3/3155/05, solved at the Department of Environmental Studies and Process Management, Faculty of Mechanical Engineering at the Technical University of Košice.

\section{References}

[1] BADIDA, M., BOSAK, M., CHOVANCOVA, J.: End-of-life vehicle recycling (in Slovak), KEGA 3/2155/04. Kosice: SjF-TU, p. 49, 2006.

[2] BADIDA, M., VARGOVA, J., HRICOVA, B.: The possibilities of the improvement of environmental performance of industrial products, MMA 2006: Zbornik radova: 9. mezdunarodna naucno-strucna konferencija fleksibilne technologije, Novi Sad, 2006. Novi Sad: Institut za proizvodno masinstvo, 2006, p. 139-140, ISBN 86-85211-96-4. 
[3] MAJERNIK, M., BADIDA, M., BOSAK, M., CHOVANCOVA, J.: A pproaches to ELV recycling in Slovakia (in Slovak), Vplyv automobiloveho priemyslu na rozvoj regionov v SR, Kosice, TU, 2005, p. 7.

[4] MAJERNIK, M., BOSAK, M., CHOVANCOVA, J.: Possibilities of component usage from ELV recycling (in Slovak), Odpady 2006, zbornik prednasok z medzinarodnej konferencie, Spisska Nova Ves, Geologia PaB, 2006, p. 310-316, ISBN 80-968214-6-6.

[5] RUSKO, M., VARGOVA, J., CHOVANCOVA, J.: Life cycle assessment and its potential in decision-making process, Industrial Toxicology 2007, Bratislava, 2007, Proceedings, p. 369-373, ISBN 978-80-227-2654-2.

[6] SCHMIDT, HAHLQVIST, FINKBEINER at. al.: Life-cycle Assessment of Lightweight and End-of-life Scenarios for Generic Compact Class Passenger Vehicles; International Journal of Life Cycle Assessment; Vol. 9, 6/2004

[7] Verwertung von Kunststoffbauteilen aus Altautos - Analyse der Umwelteffekte nach dem LCA-Prinzip und ökologische Analyse; Abschlussbericht für Forschungsvereinigung Automobiltechnik e.V.; 2005

\title{
Department of Fire Engineering \\ FSI ZU in Zilina \\ and \\ Secondary school of Fire Protection \\ MV SR in Zilina
}

Welcome you

$3^{\text {rd }}$ international conference

\section{FIRE PROTECTION AND RESCUE SERVICES}

\author{
May 28. - 29., 2008 \\ Zilina
}

We are inviting you to the third meeting of professionals in the field of fire safety which follows the conferences held in 2008. The conference will traditionally take place at the University of Zilina, Faculty of Special Engineering.

\author{
Contact address: \\ Ing. Lubica Sovcikova \\ Department of Fire Engineering \\ Faculty of Special Engineering, University of Zilina \\ 1. maja 1, 32, 01026 Zilina \\ Slovak Republic \\ Phone: +421- 41-513 6799 Fax: +421-41-513 6620 \\ E-mail: lubica.sovcikova@fsi.uniza.sk \\ Web site: www.fsi.uniza.sk/kpi
}

